Historic, Archive Document

Do not assume content reflects current scientific knowledge, policies, or practices. 



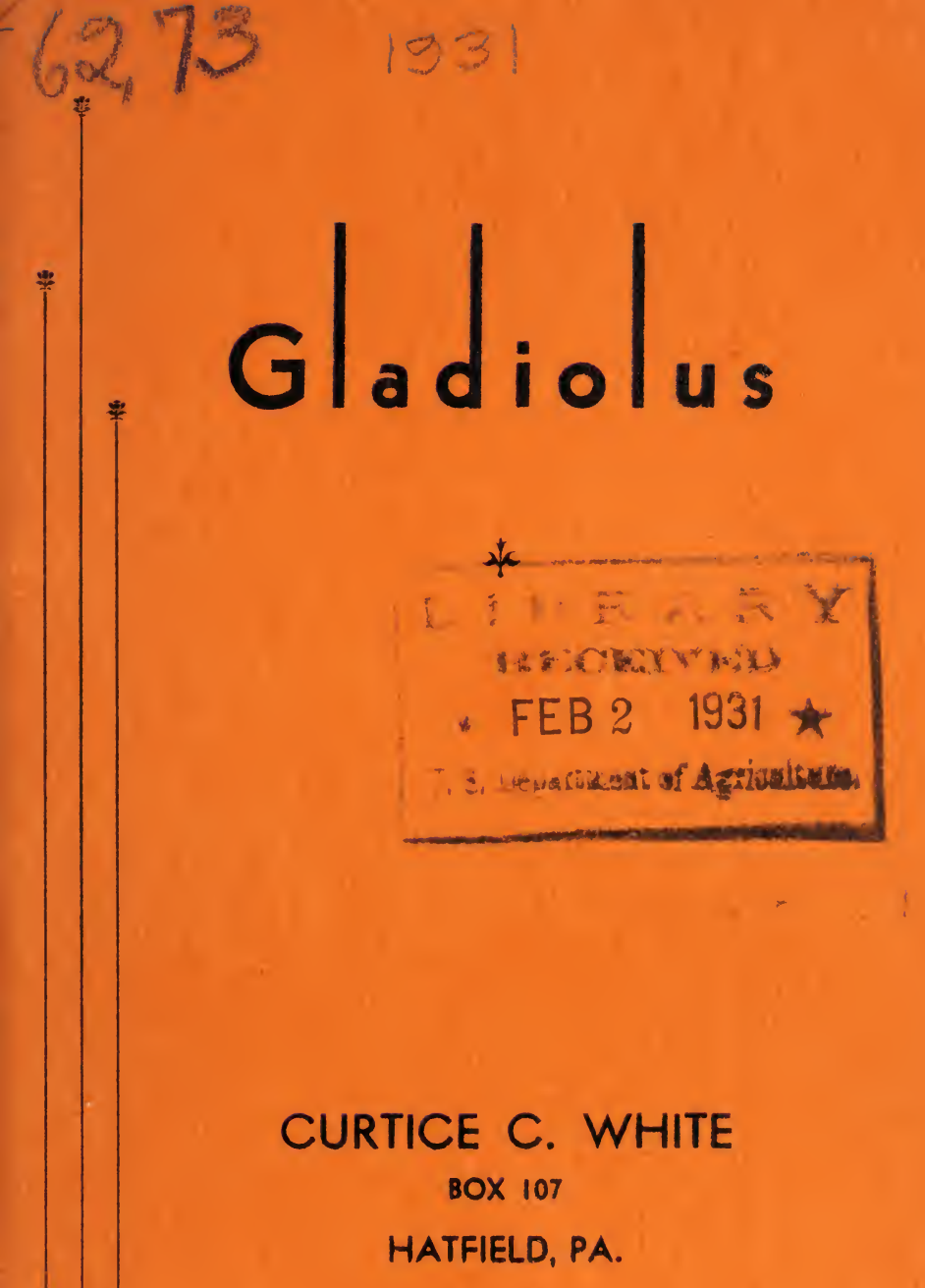




\section{Spring Bulletin, 1931}

THE past season was one of great discouragement for many of us, due to the drought, insects, etc. But we all look forward to another year, assuring ourselves that it must, indeed, be better.

We cannot say enough in favor of mulch paper. It certainly worked wonders for us, and we would highly recommend its use to others. As a means of conserving moisture and eliminating weeds, it cannot be beaten.

We would urge you to visit the second Flower Pageant to be held in Convention Hall, Atlantic City, N. J., September 5th to 10th, 1931. Those who attended the first one still remember it; but it is expected that the coming exhibit will far out-class that of last year.

The bulbs we send out are guaranteed to be strong, healthy and true to name. Anything proving otherwise will be replaced; but the results you will obtain are so far beyond our control that we cannot hold ourselves responsible for the same. Carrying charges prepaid on all orders for $\$ 1.00$ and over. Please send cash with order.

We do not issue a wholesale list, but we shall be glad to quote you prices on any quantity or size you might wish.

Please order early. We begin planting early in May and even though we try to hold some of each variety back for late orders, we frequently have to turn down orders because of late arrival.

Orders accepted subject to stock unsold. Unless specified otherwise, all bulbs will be large size. Medium size bulbs, except where single price is quoted, will be supplied at the rate of three for twice the price quoted for one large bulb. Bulblets can be supplied at the rate of one packet for the price of one large bulb.

If references are desired, communicate with the Hatfield National Bank, Hatfield, Pa. 


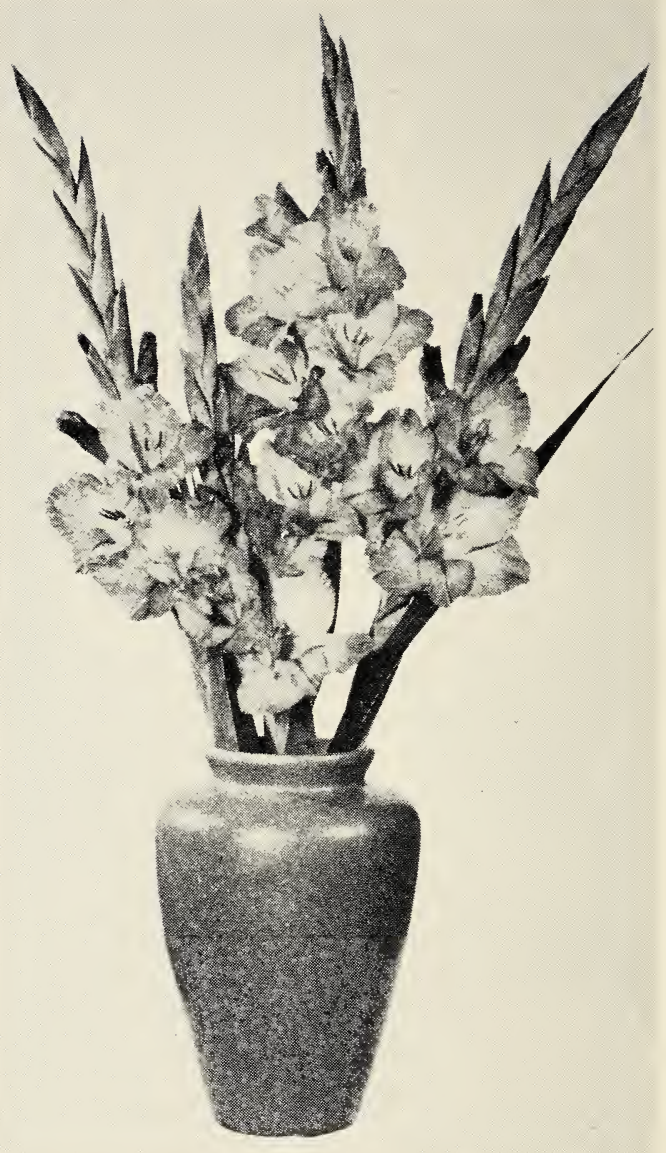

DR. NELSON SHOOK 


\section{List of Varieties}

A. E. Kunderd. Delicate salmon pink with deep colored blotch. Large heavily ruffled flower.

Ea., 20c; Doz., $\$ 2.00$

Aida. Dark blue-purple with reddish blotch. This variety blooms very early. $\quad$ Ea., 50c; Doz., $\$ 5.00$

Albatross. A milk-white flower of giant proportions, growing on a very tall spike. $\quad$ Ea., \$1.25 M., 75c ea.; S., 40c ea.; Bblts., 12 for $\$ 1.00$

Allen V. Bunce. Brilliant orange yellow with red lines in the throat. Prim grand type. Ea., 10; Doz., \$1.00 Antonia Antoinette. Large flower of soft salmon pink color. Long spike.

Ea., 20c; Doz., $\$ 2.00$

Apricot Glow. Nice clear apricot color. Good sturdy grower. Prim grand type. Ea., 15c; Doz., \$1.50

Ave Maria. A very fine light blue variety. Said to be one of Pfitzer's best.

Ea., $\$ 2.00$

M., $\$ 1.00$ ea.; S., 50c ea.; Bblts., 10 for $\$ 1.00$

Berty Snow. Lavender, with more pink in it than Minuet. Large flowers, tall plant, many blooms open at one time. Ea., 40c; Doz., $\$ 4.00$ M., 25c ea.; Doz., \$2.50; S., 10c ea.; Doz., $\$ 1.00$ Bblts., 10 for $25 c$

Betty Nuthall. Glowing orange pink with pale orange throat and light striping of carmine. Many large flowers open on a very tall spike. This variety has already made a name for itself and is a real bargain at the price asked for it. Ea., 50c; Doz., $\$ 5.00$ M., 30c ea.; Doz., $\$ 3.00$; S., 15c ea.; Doz., $\$ 1.50$ Bblts., 10 for $25 c$

Captain Boynton. Lavender overlaid on white with a large purple blotch. Ea., 10c; Doz., 90c

Cardinal Prince. Pure cardinal red. Ea., 10c; Doz., 90c Carmen Sylva. Good white. Tall straight spike.

Ea., 10c; Doz., 90c

Copper Bronze. A good novelty of true bronzy color. Prim grand type.

Ea., 10c; Doz., $\$ 1.00$ 
Coronado. White with a glossy purple, lacy blotch in the throat. Large, heavy textured blooms vith frilled edges.

Ea., $\$ 1.00$

\section{M., 60c ea.; S., 30c ea.}

Crimson Glow. Deep glowing crimson. Tall straight spike with large flowers. Old but still good.

Ea., 10c; Doz., 75c

Dr. F. E. Bennett. Brilliant flaming scarlet, the best in its color class. Many large blooms open on a long strong spike. Ea., 10c; Doz., 80c

Dr. Moody. Large early lavender. Ea., 35c; Doz., $\$ 3.50$ M., 20c ea; S., 10c ea; Bblts., 20 for $25 c$

Dr. Nelson Shook. Deep tyrian rose color. Many ruffled flowers on a very large strong growing plant.

Ea., I $5 c_{;}$Doz., $\$ 1.50$

E. B. Williamson. Large primulinus type of mallow purple color.

Ea., 10c; Doz., 75c

Elizabeth Tabor. Pale flesh pink with deeper blotch on a pale yellow throat. Crooks badly at times.

Ea., 10c; Doz., 75c

Emile Aubrun. Immense flowers of rich rose color overlaid with slaty blue. Brilliant carmine blotch in throat. Very fine smoky variety. Ea., I5c; Doz., \$I.50

Enchantress. Beautiful delicate pink. A good sized, tall-growing prim.

Ea., 10c; Doz., 90c

Fastidious. Pale pink shading to white. Large prim grand type. Crooks at times but is good for baskets.

Ea., 10c; Doz., 80c

Fontaine. Flesh pink with cream throat. This cannot be classed among the large flowers but is valuable for its attractive coloring and daintiness. Very good combined with Geraldine Farrar or any of the lavenders.

Ea., 10c; Doz., 80c

Frank J. Symmes. Peach red with flame throat. Heavily ruffled flowers. Strong grower. This variety does very well in loamy soil, but from all reports does not do well in sand.

Ea., I0c; Doz., 80c 


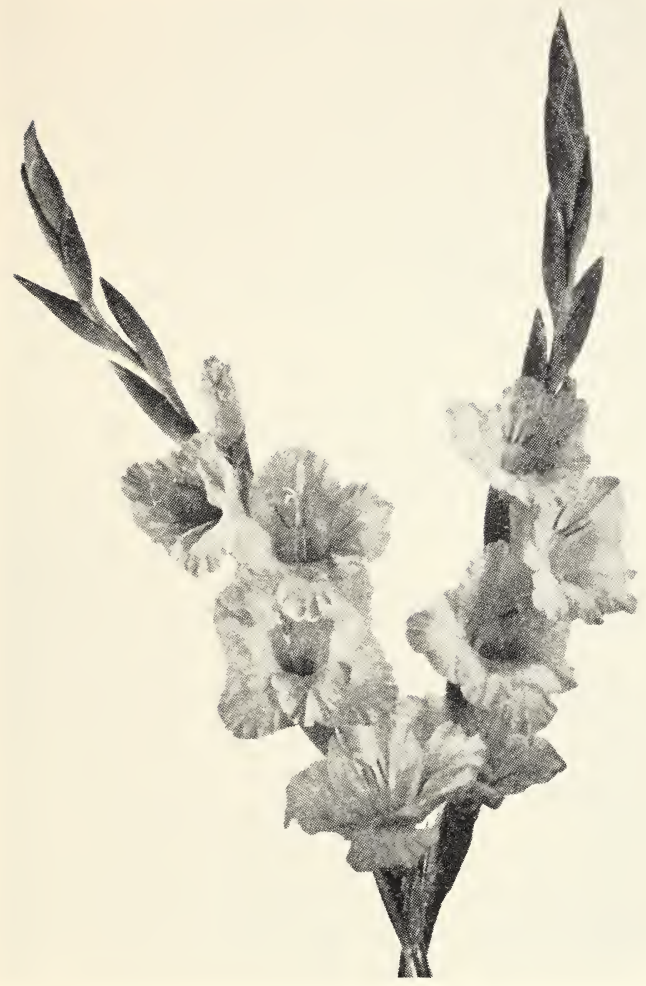

FRANK J. SYMMES

Geraldine Farrar. Beautiful violet blue with deeper blotch in the throat. This doos not grow as sturdily as some of the newer blues but it is still my favorite in that class. Ea., 20c; Doz., \$1.75

Genesee. Cream yellow prim. Ea., I0c; Doz., 80c

Giant Nymph. One of the finest of the new pinks. It is seen at most of the shows and wins its share of prizes. Flowers are large on a fine spike.

Ea., 10c; Doz., 75c 
Gloriana. A glorious variety with pure salmon color flowers. Tall, slender but strong spike. The shape of the flowers is very attractive. Ea., 15c; Doz., $\$ 1.50$

Gold. Deep golden yellow. Old but still good.

Ea., 10c; Doz., 75c

Golden Dream. A fine deep yellow. The best available. Good size blooms on a very tall spike, blooming late. Ea., 15c; Doz., \$1.50

Gold Eagle. A fine yellow that is very early. This variety did very well for us, this past season.

Ea., I0c; Doz., 80c

Golden Frills. Daffodil yellow, with red lines in throat. Edges of petals heavily ruffled. Ea., 10c; Doz., $\$ 1.00$

Golden Measure. Very large yellow flowers on a robust spike. This variety can be grown to immense size. Ea., 10c; Doz., 80c

Golden Swallow. Golden yellow, ruffled.

Ea., 10c; Doz., 70c

Heavenly Blue. Pale blue. Tall strong grower. Exceedingly beautiful when well grown. Ea., 40c; Doz., $\$ 4.00$

Helen Wills. Ivory white. A very good variety with large flowers on a tall spike. Ea., 25c; Doz., \$2.50

Hinemoa. A very odd variety from New Zealand. Deep rose, overlaid with brown, yellow throat. Ea., \$2.00 Jack London. Salmon pink with deeper stripings.

Ea., 10c; Doz., 70c

Jane Addams. Large flowers of soft lavender with a little cream color in the throat. Tall plant.

Ea., 30c; Doz., $\$ 3.00$

Longfellow. Beautiful bright pink. A good one.

Ea., 10c; Doz., 90c

Louise. A good late lavender Ea., I0c; Doz., 70c

Los Angeles. Salmon pink tinged with orange. Sometimes show the tendency of blooming again after the first spike has bèen cut. Ea., 10c; Doz., 70c

Marie Kunderd. Pure white with slight pencilling in throat. Petals ruffled. Early. Ea., 10c; Doz., 70c 
Marietta. Deep salmon pink with large blotch. Seen continually as a prize vinner at the shows.

Ea., 10c; Doz., $\$ 1.00$

Marmora. Smoky lavender gray with dull rosy blotch. Immense flowers, strong spike. This variety is the best of the "any other color" class.

Ea., 50c; Doz., $\$ 5.00$

M., 30c ea.; Doz., $\$ 3.00 ;$ S., I5c ea.; Doz., $\$ 1.50$ Bulblets, 20 for $30 \mathrm{c}$

Marshal Foch. Salmon pink with scarlet blotch in throat. Large round flowers on very vigorous robust plant.

Ea., I0c; Doz., 75c

Minuet. The very best pale lavender available. This variety can be said to be practically faultless. Large flowers, good placement, straight spike.

Ea., 30c; Doz., $\$ 2.50$

Mary Pickford. Soft creamy white with deeper cream in throat.

Ea., 10c; Doz., 70c

Ming Toy. Large prim of deep saffron color.

Ea., 10c; Doz., 70c

Mother Machree. Soft smoky lavender blended with pink and gray. Created a sensation when first exhibited at Hartford and has been popular ever since.

Ea., $\$ 5.00$

$$
\text { M., } \$ 3.00 \text { ea.; S., } \$ 1.50 \text { ea.; Bblts., 25c ea. }
$$

Mrs. F. C. Hornberger. White. Grows to a very large size both in flower and spike. Ea., 15c; Doz., $\$ 1.50$

Mrs. F. C. Peters. Good late lavender with deeper blotch. Straight grower with flowers well placed.

Ea., 15c; Doz., $\$ 1.50$

Mrs. Gertrude Pfitzer. Light blue with violet center. Good.

Ea., $75 c$

M., 50c ea.; Doz., $\$ 5.00 ;$ S., 30c ea., Doz., $\$ 3.00$ Bblts., 12 for $75 c$

Mrs. H. E. Bothin. Flesh pink with red blotch in throat. Heavily ruffled.

Ea., 10c; Doz., 70c

Mrs. Galbraith. Good salmon pink. Large and early. Many flowers open. Strong grower. This is one of the Mair varieties imported from Scotland, which are becoming so popular.

Ea., $40 c_{i}$ Doz., $\$ 4.00$ 
Mrs. John R. Walsh. Soft geranium pink with brilliant scarlet blotch. Heavily ruffled. Larger and brighter color than Mrs. H. E. Bothin. Long spikes.

$$
\text { Ea., IOc; Doz., } \$ 1.00
$$

Mrs. Leon Douglas. Very large flowers of begonia rose striped scarlet. Can be grown to gigantic size when given plenty of water. The flower occasionally comes with clear color showing almost no striping.

Ea., 10c; Doz., 80c

Mrs. P. W. Sisson. Beautiful cameo pink. Large blooms with many open at a time. Ea., 10c; Doz., $\$ 1.00$

Mrs. Van Konynenburg. Deep blue. Tall straight spikes. very good. Ea., 25c; Doz., $\$ 2.50$

Nancy Hanks. Apricot blended into orange pink. It never grows crooked and comes good under all conditions.

Ea., 10c; Doz., 80c

Nixie. Pure soft pink, with perfectly straight spike and several blooms open at the same time. Very fine in combination with a soft lavender such as Minuet or a pale yellow. Ea., 10c; Doz., 80c

Orange Queen. Orange colored prim with red marking in throat. Large. Ea., 10c; Doz., 80c

Orchid. Pale lavender pink shading to cream in throat. Very attractive type, said to resemble an orchid.

Ea., I5c; Doz., $\$ 1.50$

Osalin. Lovely coral pink with soft orange markings in throat. Large flower and strong grower. A very desirable variety. Ea., 10c.; Doz., \$1.00

Paul Pfitzer. Good velvety purple. Large flowers and good plant. One of the best in its color.

Ea., 30c; Doz., $\$ 3.00$

Pearl of California. Large flowers of clear pale pink. Very sturdy grower with a very long spike of bloom. Ea., 25c; Doz., $\$ 2.50$

Persia. Very deep red, almost black. Ea., 10c; Doz., 90c

Purple Glory. Deep purplish maroon. Large heavily ruffled blooms of wonderful substance, on a strong spike. Very good.

Ea., IOc; Doz., $\$ 1.00$ 


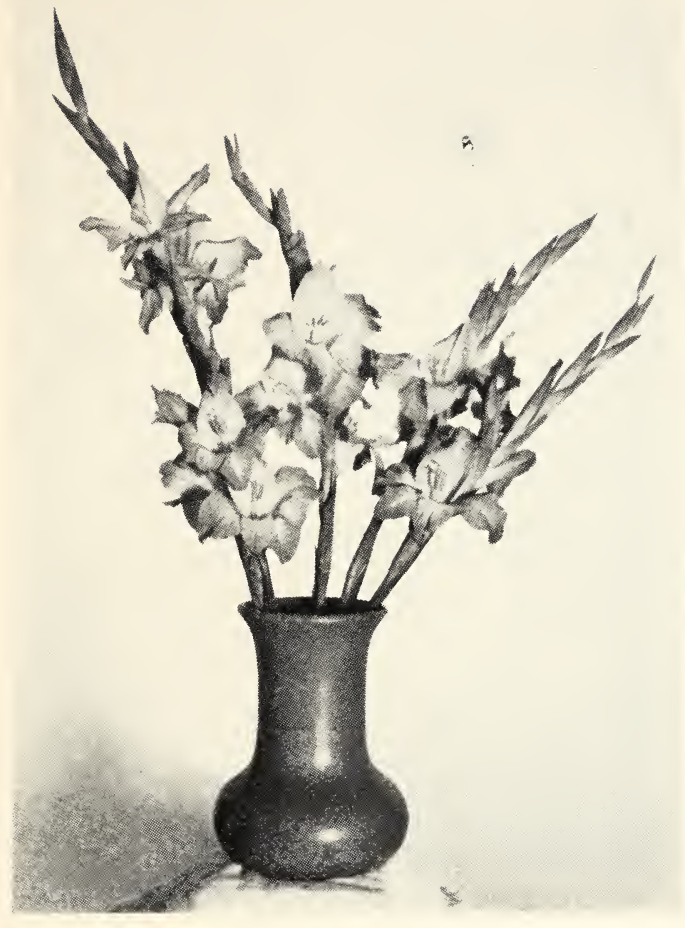

ROSE ASH

Pfitzer's Triumph. Immense blooms of salmon orange color on a tall straight spike. Flowers have perfect placement and open well. It should never be left in the strong sun but should be cut as soon as open. A really wonderful variety which blooms well from small bulbs. $\quad$ Ea., 30c; Doz., $\$ 3.00$ M., 20c ea.; Doz., $\$ 2.00 ;$ S., 15c ea.; Doz., $\$ 1.50$ Bblts., 12 for $25 \mathrm{c}$

Primrose Princess. Pale primrose yellow. Large flowers on a strong spike and early. Ea., 20c; Doz., \$2.00 
Purple Queen. Good ruffled purple flower. Straight spike and desirable. $\quad$ Ea., 25c; Doz., \$2.50

Queen Mary (Salbach). Bright pink with scarlet blotch on a pale yellow throat. Heavily ruffled.

Ea., 15c; Doz., $\$ 1.50$

Quakeress. A pure gray lavender with creamy throat. Well named.

Ea., 25c; Doz., $\$ 2.50$

Red Tornado. Deep crimson red with darker blotch. Late.

Ea., $\$ 1.00$

Rippling Waters. Cream blended with pink. Large flowers. Good exhibition form. Ea., 75c

Rita Beck. Large, shell pink blooms. Strong grower. Very highly recommended by those who know.

Ea., 30c; Doz., $\$ 3.00$

Rose Ash. "Ashes of rose" color. Grayish rose with pale yellow throat. Placement is not always good, but color makes up for that with a great many people.

Ea., 10c; Doz., 70c

Rose Mist. Rose red with buff line around edge of the petals. Good grower. Striking and very attractive.

Ea., I5c; Doz., $\$ 1.50$

Royal Purple. Bright purple. Tall slender grower. Flowers of good size. Did well last year in spite of the drought. $\quad$ Ea., 35c; Doz., $\$ 3.50$

Scarlet Bedder. Bright glowing scarlet. Prim grand type.

Ea., I5c; Doz., $\$ 1.50$

Scarlet Princeps. Soft raspberry red. Round flowers of good size. The red blends very well with other colors. Ea., 10c; Doz., 80c

Senorita. Orange shading to salmon. Orange throat with carmine penciling. Large flowers of unusual shape. Very striking and rapidly becoming popular.

Ea., 50c; Doz., $\$ 5.00$ M., 30c ea.; Doz., $\$ 3.00$; S., 20c ea.; Doz., $\$ 2.00$ Bblts., 12 for $50 \mathrm{c}$

Star of the Sea. Peach red with a brownish cast. Large flowers on a sturdy spike. Very beautiful. Ea., 40c

Sweet Lavender. Light lavender with deeper blotch on yellow throat. Early. Ea., 10c; Doz., 80c 


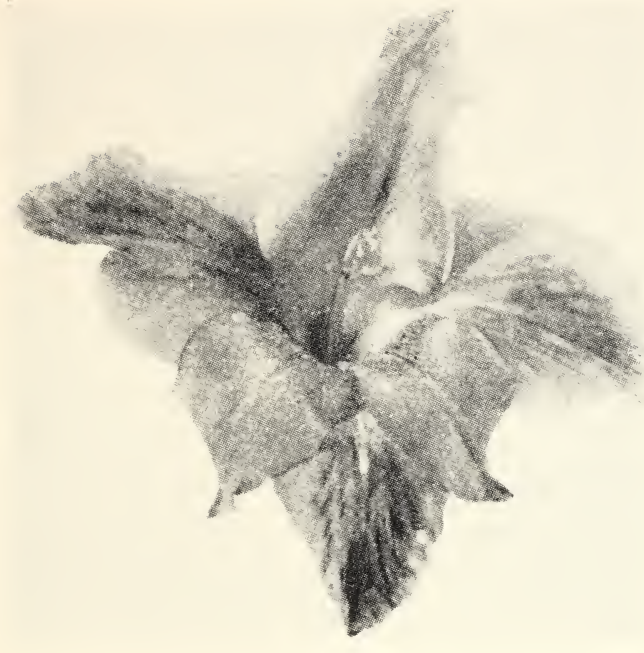

Mrs. LEON DOUGLASS

Sword of Mahomet. Unusual dusky color with a combination of purple and brown. It is so odd that many people do not like it, but those who are looking for something out of the ordinary will certainly find it in this variety. Ea., 20c; Doz., $\$ 2.00$

Tobersun. Soft yellow. Very nice flower on a good straight spike. One of the "coming" new varieties. Ea., $\$ 1.00$ M., 60c ea.; Doz., \$6.00; S., 35c ea.; Doz., $\$ 3.50$ Bblts., 12 for $\$ 1.00$

Trudel Grotz. Enormous salmon with bright red blotch. Ea., 20c

Tycko Zang. Salmon pink. Large flowers, vigorous plant, very prolific. Late. Ea., 10c; Doz., 70c

Uhlan Chief. Vermilion scarlet with dark markings in throat. Very brilliant Ea., 10c; Doz., 80c 
Veilchenblau. Deep violet blue. Large flowers on a good spike. Very popular. Ea., 30c; Doz., $\$ 3.00$

Victor. Bright scarlet with white throat. A good variety from Australia.

Ea., 40c

W. H. Phipps. La France pink overlaid with light salmon. 10 to 15 very large flowers open at once. The standard by which exhibition glads are judged. Wonderful.

Ea., 10c; Doz., 90c

White Butterfly. Cream white prim. Good mixer.

Ea., 10c; Doz., 70c

Wm. Kent. This is a lovely glad-creamy shell pink, with many large heavily ruffled flowers open at one time. Makes a good strong spike and has splendid keeping qualities.

Ea., 25c; Doz., $\$ 2.50$

Winged Victory. Very large pink flowers. They measure 8 inches across in California-over 7 inches in New Jersey.

Ea., $\$ 1.00$

\section{Bblts., 12 for $\$ 1.00$}

Yellow Wonder. Light yellow with deeper throat.

Ea., 10c; Doz., $\$ 1.00$

Mixture.

30 for $\$ 1.00 ; \$ 2.50$ per 100

If you are unacquainted with the different varieties, we shall be glad to make up collections to meet your desires. Let us know how much you wish to spend, about how many bulbs you want and your color preferences.

We can also supply you with Iris and Tulips. Prices furnished upon request. 
in $y=-x$
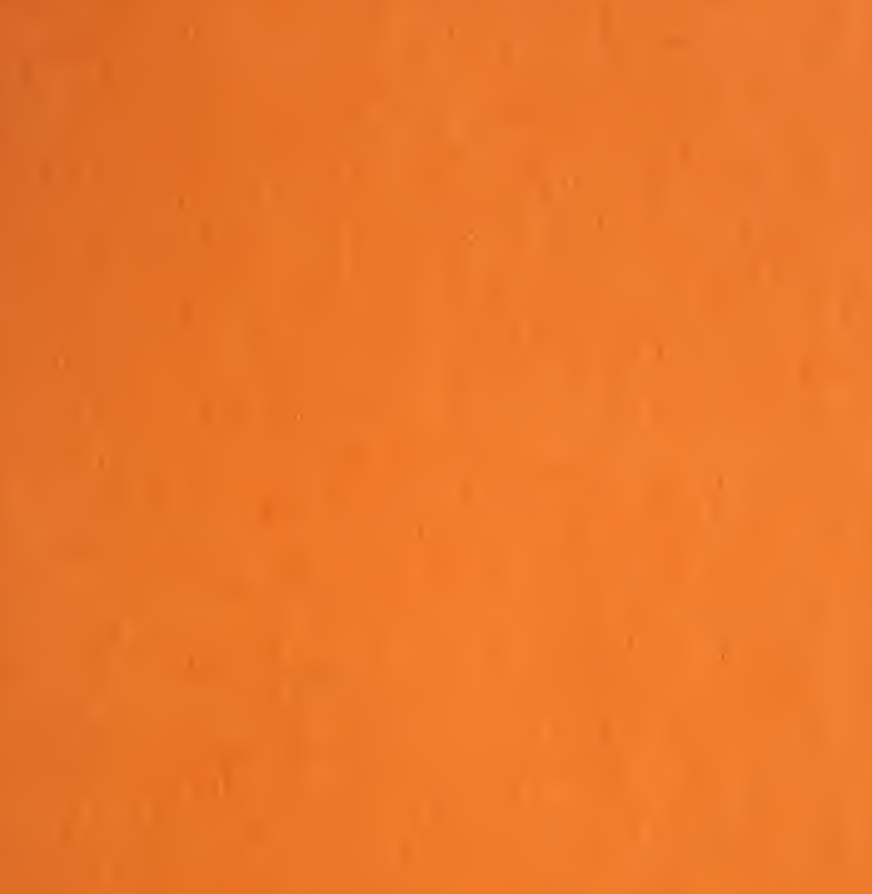<smiles>C1CCCC1</smiles>
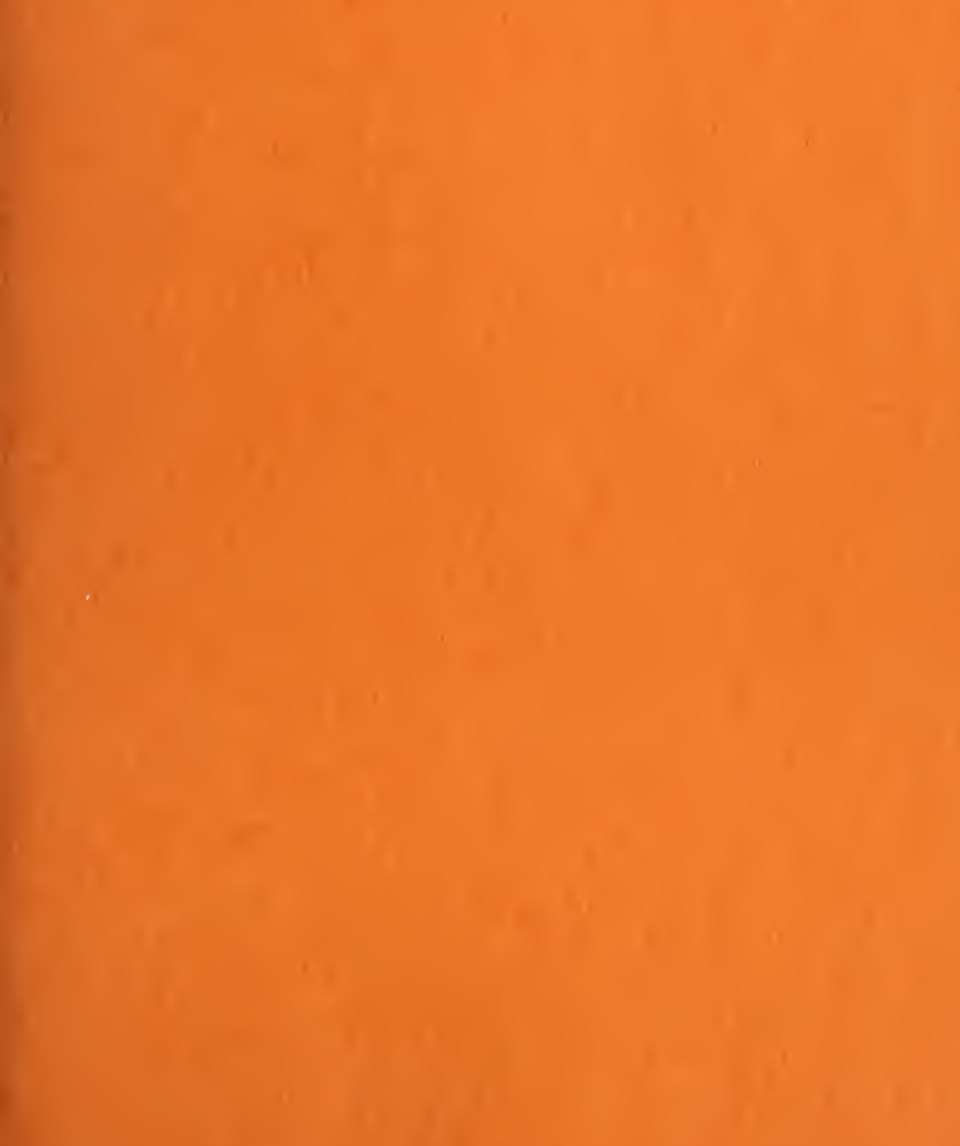

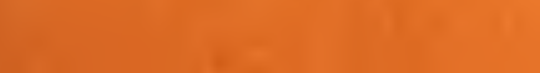


